\title{
A LONGITUDINAL STUDY OF ISP REACTIONS TO AUSTRALIAN INTERNET CONTENT REGULATION LAWS
}

\author{
Sigi Goode \\ School of Business and Information Management \\ Faculty of Economics and Commerce \\ Australian National University \\ Acton ACT 0200 \\ sigi.goode@anu.edu.au
}

\begin{abstract}
This paper discusses a longitudinal study which surveys a targeted selection of Australian ISPs to determine both initial and subsequent effects of and attitudes towards the legislation. The paper observes that, initially, ISPs were generally opposed to the legislation, offering stiff opposition to its introduction. The initial results suggested dissatisfaction with the legislation on the part of ISPs, and foreshadowed adverse effects on the online industry. Concerns were also raised that the legislation would not be effective. Two years later, however, ISPs had generally observed little change in operations, arguing that the legislation had had little overall effect. The study also raises a number of interesting issues that are outside the scope of this paper. These issues merit further research.
\end{abstract}

Keywords Internet Regulation, Electronic Commerce, Internet Service Provider

\section{INTRODUCTION}

When the Internet began receiving patronage as a commercial (Vadapalli and Ramamurthy 1997, Hallahan 2004), educational (Stair and Reynolds 1998), informational (Applegate et al. 1996, Xiao et al. 2004), social (Brien 1996, Fan 2005), and academic (Salam et al. 1997) tool, observers around the world saw the number of Internet users increase at a dramatic rate (Chiou 2004). Coincidentally, a number of governments began making attempts to regulate the access to, and provision of, online content (Applegate et al. 1996, Strauss and Rogerson 2002).

For some time, the research literature saw substantial debate over the efficacy, value and effect of such regulation. Teo et al. (1997) discussed the importance of governmental and legislative support in the adoption of technology in industry, and note the positive effects of government regulation and endorsement of online commerce in Singapore. Fan (2005) and Soh et al. (1997) observed similar findings within Asia in general. Hulsink and Van Bolhuis (1998) argued that the effective implementation and policing of such legislation would enable e-commerce strategies to flourish by improving trust and customer confidence (consistent with Gefen and Straub 2004). Conversely, the adverse effects of enforced regulation may be alleviated through voluntary co-operation of firms with regulators (Xiao et al. 2004, Williams 1994) or with each other through co-optation (Barringer and Harrison 2000). Also, Internet use and policy development may vary between countries, so legislation for one state may not work for another (Baumer et al. 2004).

At the same time, recent global events have changed the way personal and national security are viewed. This concern has extended to the World Wide Web, as countries attempt to legislate their national online communications infrastructures. ISPs are particularly important in this strategy for a number of reasons. First, despite recent growth in the uptake of broadband (Stern et al. 2004) and wireless services, much online access still requires 
conventional public switched telephone networks (PSTN) (Naldi 2002). Internet Service Providers (ISPs) offer users Internet in return for payment (Chiou 2004) and, accordingly, the ISP is very much the "entry point to the e-market" (Francalanci et al. 2001:145).

Many have argued that the ISP market should be regulated in some way. Australian users are able to complain to the Telecommunications Industry Ombudsman (TIO), however that body has been largely powerless to assist users with bankrupt ISPs or online content issues. To this end, the Internet Industry Association of Australia (the IIA) was formed as a membership and lobby group for organisations in the online industry (including, for example, website developers, law firms and ISPs). The group has also acted in an advisory capacity to the Australian Broadcasting Authority (ABA) in the development of this online legislation. Other than the guidelines provided by these bodies, very little legislation pertains directly to ISPs and their operation.

Australia is one country which has commenced a program of Internet regulation, by prescribing a ratings scheme for online content at the ISP source. This legislative bill was among the first in the world, and some longitudinal analysis of its efficacy would be benefit practitioners and policy makers. In addition, the popularity of the Internet and the potential effects of this legislation suggest that this analysis would benefit to the information systems research body by providing new evidence as to the value of online content regulation.

This paper documents the findings of an ongoing study into network regulation. The first stage of the study is discussed in Goode (2002), and the reader is directed to that work for additional context. The rest of this paper is structured as follows. In order to "report sufficient contextual and environmental conditions of their research to enable other researchers to judge the limitations of the conclusions" (Nunamaker et al. 1991), the next section provides a brief overview of Internet Service Providers and the new ABA legislation. The study's research method is then discussed. The paper then discusses the results, which is followed by analysis and implications. Finally, conclusions and areas for further research are explored.

\section{DEFINITIONS}

It is first necessary to establish nomenclature and definitions for the terms used in the paper, especially with regard to legal terminology. Hancher and Moran (1989:271) define regulation as "involving...the design of general rules, the creation of institutions responsible for their implementation, the clarification of the exact meaning of a general rule in particular circumstances and the enforcement of the rule in those circumstances".

The term, "Bill" describes a draft statute that has not yet been passed through parliament (Cook et al. 2005). The term, "Act" describes a statute or an element of legislation (Cook et al. 2005). "Legislation" describes both the acts enacted by parliament, described above, and the subordinate laws developed by authorised groups (such as a city council or the Governor-General) (Cook et al. 2005).

\section{THE ABA LEGISLATION}

The legislation was an amendment to the Australian Broadcast Services Act (1992) and was designed to work in concert with an ISP Code of Practice. The legislation was designed to restrict online "content that is illegal or highly offensive, or maybe harmful to children" at the access provider. The legislation does not apply to private networks or distribution media (such as electronic mail or LANs). The legislation allows members of the public to 
complain to the Australian Broadcasting Authority (ABA) about material on the Internet that they find offensive. Once a complaint has been made, the ABA investigates the content and assigns it a viewing classification similar to those awarded to films (for instance, " $\mathrm{X}$ ", "R", or "PG"). If the material receives an "X" rating, a notice may be issued, based on "technical and financial feasibility", to either remove the material (if the host is local) or block the material (if the material is outside of Australia). Material that receives an "R" rating is deemed unsuitable for general access and must be restricted by way of an age verification system. Once the ABA has issued such an interim removal notice, the ISP has a full business day to comply with the notice. If the ISP does not comply, fines of AUS $\$ 5,500$ for an individual or AUS $\$ 27,500$ for a company (Adams and Burke 1999) may be imposed.

The legislation specified the creation of an ISP Code of Practice, which is similar in many respects to the ABA Television Code of Practice (originally designed to give television viewers an avenue for complaint). This Code of Practice, developed by the IIA in conjunction with the ABA, is not mandatory until the ABA directs a given ISP to the Code, whereupon the Code must be followed. The Code of Practice makes provision for dealing with customer complaints and makes special distinction between the ISP's responsibilities with respect to content available outside of Australia and sites hosted within Australia. The Code also describes, in broad terms, methods for filtering or blocking material through client-side software such as Net Nanny and Cyber Patrol. Content monitoring and sitespecific online age verification systems are also discussed.

The bill, in its current form, has been in development for several years, and planning began in late 1995 (De Souza 1999) with the first Senate Committee investigation into the Regulation of Online Services. Table 1 gives a chronological overview of the legislation's development. Development involved submissions from lobby groups, the Commonwealth Scientific and Industrial Research Organisation (CSIRO) and the Internet Industry Association. Alternatives to the legislation, including client-side filtering software such as Net Nanny, were deemed too technical and too difficult to enforce for widespread use.

Table 1: Timeline of significant events during the development of Internet Regulation Legislation

\begin{tabular}{|ll}
\hline 21-Jun-91 & $\begin{array}{l}\text { Senate Select Community Standards Committee established. Initially } \\
\text { tasked with reporting on telephone sex services, the committee will } \\
\text { eventually also comment on television material and computer game } \\
\text { content. }\end{array}$ \\
24-Jul-95 & $\begin{array}{l}\text { The Minister for Communications and the Arts directs the ABA to } \\
\text { conduct an investigation into the content of online information and } \\
\text { entertainment services, including Internet services. }\end{array}$ \\
2-Mar-96 & $\begin{array}{l}\text { 1996 Australian Federal Election. Liberal/National Party Coalition } \\
\text { wins power. Policy statements do not mention the Internet or its }\end{array}$ \\
1-Jun-97 & $\begin{array}{l}\text { Segulation. } \\
\text { Senate Select Community Standards Committee releases "Report on } \\
\text { the Regulation of Computer On-Line Services", which recommends } \\
\text { support for criminal prosecution and police intervention of online } \\
\text { systems } \\
\text { Select Community Standards Committee is disbanded. The Senate } \\
\text { Select Committee on Information Technologies is formed in its } \\
\text { place. }\end{array}$ \\
&
\end{tabular}




\begin{tabular}{|c|c|}
\hline 16-Dec-97 & $\begin{array}{l}\text { Australian Chief Censor comments that it will be impossible to ban } \\
\text { Internet content, regardless of legislation }\end{array}$ \\
\hline 14-Jun-98 & $\begin{array}{l}\text { Senate Select Committee on Information Technologies scheduled to } \\
\text { convened to examine internet self-regulation. Imminent Federal } \\
\text { election means the meeting does not take place. }\end{array}$ \\
\hline 3-Oct-98 & $\begin{array}{l}1998 \text { Australian Federal Election. Liberal/National Party Coalition } \\
\text { wins power, featuring Internet regulation policy as part of election } \\
\text { platform }\end{array}$ \\
\hline 19-Mar-99 & $\begin{array}{l}\text { Minister for Communications, IT and the Arts announces new } \\
\text { content classification bill. Days later, the IIA meet with the Senator } \\
\text { and other government officials to clarify the Bill }\end{array}$ \\
\hline 21-Apr-99 & First Senate reading of Bill \\
\hline 27-Apr-99 & $\begin{array}{l}\text { Senate Select Committee on Information Technologies meets for the } \\
\text { first time to discuss the Bill }\end{array}$ \\
\hline 11-May-99 & $\begin{array}{l}\text { Senate Select Committee on Information Technologies tables } \\
\text { findings from meeting of April 27, arguing that the Bill should be } \\
\text { approved in its current form }\end{array}$ \\
\hline 26-Мay-99 & Senate passes Broadcasting Services Amendment Bill \\
\hline 30-Jun-99 & $\begin{array}{l}\text { House of Representatives passes Broadcasting Services Amendment } \\
\text { Bill }\end{array}$ \\
\hline 4-Jul-99 & First survey of this study takes place \\
\hline 16-Dec-99 & $\begin{array}{l}\text { ABA registers ISP Content Codes, as required by the Broadcasting } \\
\text { Services Amendment }\end{array}$ \\
\hline 1-Jan-00 & $\begin{array}{l}\text { Broadcasting Services Amendment Bill and ISP Content Codes } \\
\text { come into effect }\end{array}$ \\
\hline 8 -Nov-00 & $\begin{array}{l}\text { South Australian Attorney-General introduces a Bill into South } \\
\text { Australian State parliament "aimed at making it illegal to make } \\
\text { offensive material available on the internet" }\end{array}$ \\
\hline 8-Mar-01 & Internet Industry Code of Practice registered with ABA \\
\hline 1-Jun-01 & ISP Content Codes due for formal review \\
\hline 7-Nov-01 & $\begin{array}{l}\text { Bill is introduced in NSW State Parliament to make it a criminal } \\
\text { offence to make online content available to adults if that content is } \\
\text { unsuitable for minors }\end{array}$ \\
\hline 4-Nov-01 & Follow-up survey of this study takes place \\
\hline 4-Dec-01 & Both houses of NSW Parliament pass NSW Bill \\
\hline 5-Dec-01 & $\begin{array}{l}\text { NSW Attorney-General refers the NSW Content Regulation Bill to } \\
\text { Standing Committee on Social Issues for inquiry and comment }\end{array}$ \\
\hline
\end{tabular}

Sources: Gibson (2000), Libertus.net (2005)

\section{RESEARCH METHOD}

\section{Theoretical Framework}

The analysis of technology regulation and legislation has received some sporadic attention in the research literature, however very little attention has been given to the regulation of 
the Internet in particular. This is unsurprising, given the global nature of the technology and the fact that conventional legislation for traditional environments may not be suited to the dynamic structure of the World Wide Web (Post 1995). Accordingly, few frameworks exist for researching the effects of Internet regulation. Given this dearth of literature and the exploratory nature of this research, this paper is positioned within a policy analysis framework as developed by Easton (1957) and refined by Sharkansky (1970), Rose (1973) and Hogwood and Gunn (1991). The framework is shown in Figure 1.

IS readers may observe the resemblance between the appearance of this model and that of the System Development Lifecycle (SDLC). The element of "feedback", in particular, also suggests similarity to the general systems model: indeed, Easton (1957), in passing, described this model as a system. It is also interesting to note that opponents of the Policy Analysis framework make similar arguments to those put forward by critics of the SDLC. Specifically, these critics argue that the framework is inflexible, that it prohibits activity in two stages simultaneously, and that the stages in reality are not so clearly delineated (Stephens 1972). This study is particularly interested in the "Impact and Evaluation" stage of the model, and aims to add context to the analysis by exploring this impact longitudinally.

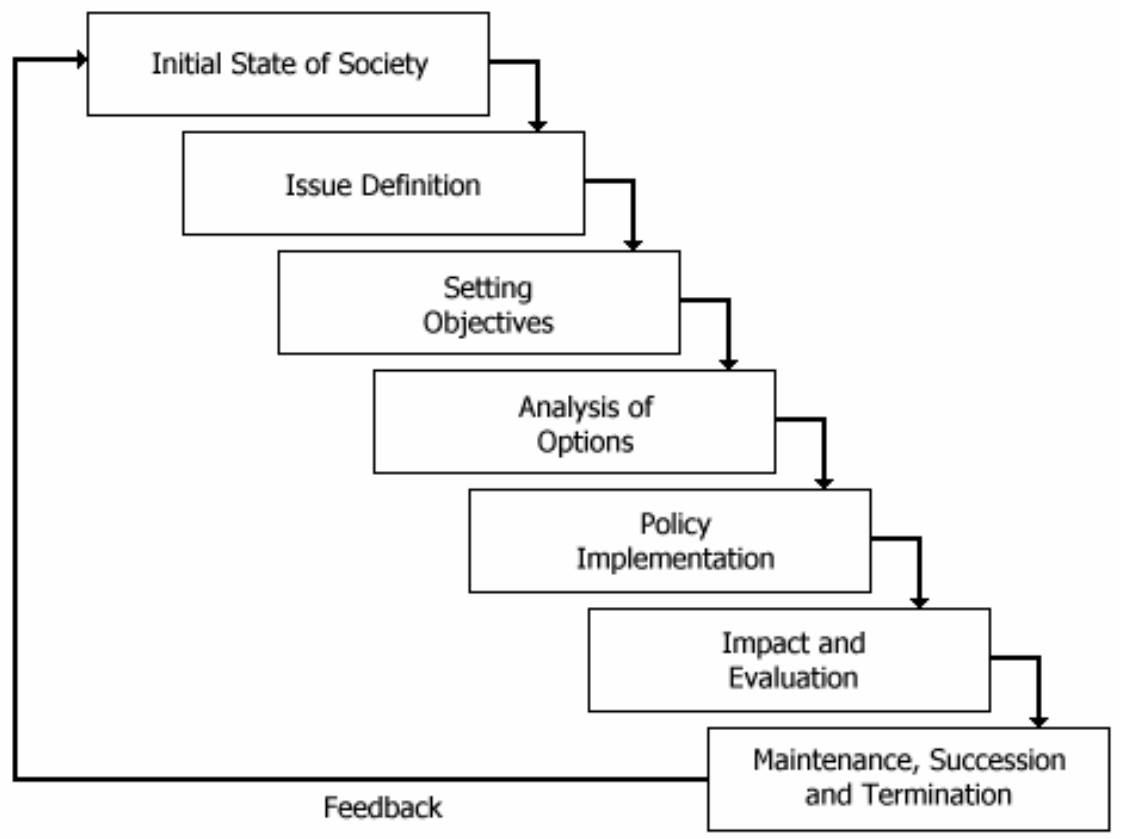

Figure 1: Policy Analysis Feedback Framework

\section{Approach}

A number of research methods are available to the IS scholar. This research is concerned with the ex post facto analysis of a particular phenomenon. Cook and Campbell (1979) 
argue the importance of sound method with respect to such research: ex post facto analysis makes no use of pre-testing, hence threatening the inference of causality in the findings. Galliers (1992) analyses approaches to social measurement within the Information Systems discipline including the laboratory experiment, archival research, the case study and survey methods. Within the Information Systems discipline, the survey method has received the most use, and has been found to consistently provide usable results (Straub 1989). Consistent with the inference vulnerabilities of ex post facto research discussed by Cook and Campbell (1979), Galliers argues that the survey method may give little insight into causal relationships, can be open to respondent and researcher bias, and only portrays the state of affairs at a single point in time. However, Galliers also argues that a large number of variables can be examined under real world conditions in a short space of time.

Kerlinger (1986) argues that behavioural survey research can be divided into explanatory research and exploratory research. The former seeks causal and correlative relationships between variables within a given phenomenon. Often, this method tests hypotheses that have been developed over time. The latter aims to better understand a phenomenon within the formative stages of a topic area's development (Malhotra and Grover 1998). Such research acknowledges that, for any phenomenon, there may be multiple objective points of view. Such perspectives may exhibit differences, however each may be intrinsically valid (Walsham 1993) and is hence particularly useful in the early stages of research (Dubin 1978).

Grover and Malhotra argue that while exploratory survey research may lack causal rigour, the method's power can be augmented using longitudinal analysis, whereby a given phenomenon or unit of analysis can be revisited over time in order to better quantify any changes taking place. Such an approach also assists in triangulating the research findings and serves to improve the value of the research study to the wider research community. This paper admits the shortcomings of exploratory research, however observes the immaturity of research in the area. This study hence takes a longitudinal approach to examining the phenomenon within an exploratory context. This analysis is also guided by the literature on survey method (notably Dillman 1978 and, in an IS context, Straub 1989), and the burgeoning literature on network regulation.

Data were required from ISPs of varying sizes and geographic locations. The data had to be obtained quickly so as to enable the analysis of initial reactions to the enactment of the legislation. Telephone (Dillman 1978) and postal/email questionnaires (Schuldt and Totten 1994) were the two survey methods that afforded speed and geographic disparity. Email surveys may be problematic, as email messages run the risk of being labeled as unsolicited junk mail ("spam"), or filtered out and not read. Network difficulties may mean an email message does not get delivered for some days. There is evidence in the literature that respondents may be reluctant to complete conventional postal surveys, even when reminded that the results are urgently required (Diamantopoulos and Schlegelmilch 1995). Telephone surveys were preferred to email surveys as they allow respondent's answers to be probed for further information about the issues under investigation (Hessler 1992). Researchers in the literature have observed that comparison between data sets acquired using different media are not always valid (Liefeld 1988); in the interests of consistency the telephone survey method was used for both the initial and subsequent stages of the study.

\section{Survey Design}

This phased of the study used a similar instrument as was used in the first stage of the 
study. A literature search was initially used to gather established survey questions from other studies. This literature search revealed few such questions. Baldwin et al. (1995) develop a general framework of questions to ask when exploring regulatory intervention, and Hosein and Whitley (2002) apply it with success to the analysis of e-commerce regulatory intervention. Ramsay (1985) offers a similar framework for examining regulation in consumer marketplaces, as follows:

- Why is regulation introduced for an area?

- How is the form of the regulatory intervention determined?

- How is the process of introducing and implementing the regulation managed?

This paper contextualises the Baldwin and Ramsay frameworks by exploring Internet regulation longitudinally. As this study is concerned with determining the effects of and attitudes towards the legislation, the survey focused on the third point of this framework. Respondents were asked for demographic information and questions concerning:

- The effect of the legislation on the ISP's operations

- The nature of feedback received from any groups (e.g. users, clients)

- Potential effects on the online industry

- General legislation implementation issues

- Anecdotal comments on the legislation itself to contextualise their earlier comments

Questions were phrased in as objective a manner as possible (consistent with Anastasi 1988). A copy of the survey instrument is included in Appendix A.

\section{Administration}

When administering the surveys, recommendations from other researchers in the area were taken into account. Before surveying began, a list of potential respondent queries and prepared answers was generated so that each respondent would be given the same information about the study (Dillman 1978). This information sheet contained pre-written answers to potential questions concerning anonymity (Stanton 1998), the origin of the survey (Fraser et al. 1988, Schneider and Johnson 1995), the eventual destination of the results, and a brief overview of the legislation. The answer sheet also included a "Don't Know" (DK) option, which Graeff (2002) and Hawkins and Coney (1981) argue can reduce uninformed response bias. Where possible, the ISP manager was sought to answer questions (Frohlich 2002), and all survey respondents were given the opportunity of receiving a copy of the final research report (Katzer et al. 1982). Respondents were reminded that this was an independent study being sponsored by an established academic institution (Schneider and Johnson 1995, Bruvold and Comer 1988), and care was taken to avoid leading respondents or otherwise biasing their replies (Klassen and Jacobs 2001).

The survey instrument was pre-tested before it was put into operation (Straub 1989). The pre-test revealed a reluctance on the part of many ISPs to participate in surveys. Based on these findings, the survey was restructured so as to remove four questions concerning competitive strategy and operations, and care was taken to remind respondents that these questions were optional. The same basic instrument was reused in the second phase so as to make good use of the pilot testing undertaken in the first round of surveying.

Twenty-four months later, in 2001, a follow-up survey was conducted. The goal in this second stage of surveying was to follow-up on the original group of respondents. In this 
vein, bankruptcy and merger documents held by the Australian Securities and Investment Commission (ASIC) were examined in order to determine the current state of each of these original respondents. Two ISPs had been purchased by other ISPs and were now whollyowned subsidiaries. Both of these ISPs were still in existence, albeit under new names. These ISPs were included in the follow-up survey.

\section{RESPONDENT PROFILES}

Surveying during both initial and follow-up implementations was spread over two days. In the first phase, each phone interview took approximately fifteen to twenty minutes. In the second phase, interviews took between twenty and thirty minutes on average. After the interview, additional time was used to recap the conversation and make sure all salient points were noted. In order to improve accuracy, demographic details were triangulated against data from the Australian ISP Directory (http://www.australianispdirectory.com). Interestingly, one large national ISP answered the survey but declined to participate in the study. Their responses have been discarded. Table 2 details the demographic breakdown of the ISP respondents from the first phase.

\begin{tabular}{|c|c|c|c|c|c|c|c|c|}
\hline & \multicolumn{4}{|l|}{ Phase 1 } & \multicolumn{4}{|l|}{ Phase 2} \\
\hline & $\begin{array}{l}\text { Network } \\
\text { Spread }\end{array}$ & $\begin{array}{l}\text { Number of } \\
\text { Clients }\end{array}$ & $\begin{array}{l}\text { Access } \\
\text { Points }\end{array}$ & ISP Age & $\begin{array}{l}\text { Network } \\
\text { Spread }\end{array}$ & $\begin{array}{l}\text { Number of } \\
\text { Clients }\end{array}$ & $\begin{array}{l}\text { Access } \\
\text { Points }\end{array}$ & ISP Age \\
\hline $\begin{array}{l}\text { ISP } \\
1 \\
\end{array}$ & International & N/A & 7 & $\begin{array}{l}8 \\
\text { months }\end{array}$ & $\begin{array}{l}\text { Internation } \\
\text { al }\end{array}$ & N/A & 7 & 2.5 years \\
\hline $\begin{array}{l}\text { ISP } \\
2\end{array}$ & International & N/A & 8 & N/A & & & & \\
\hline $\begin{array}{l}\text { ISP } \\
3^{\mathrm{e}}\end{array}$ & National & N/A & 5 & 2.5 years & & & & \\
\hline $\begin{array}{l}\text { ISP } \\
4^{\mathrm{d}}\end{array}$ & National & N/A & 30 & 3 years & National & 70,000 & 60 & $\begin{array}{l}18 \\
\text { months }\end{array}$ \\
\hline $\begin{array}{l}\text { ISP } \\
5^{\mathrm{a}}\end{array}$ & National & 150 & N/A & 4 years & & & & \\
\hline $\begin{array}{l}\text { ISP } \\
6\end{array}$ & Statewide & 200 & 1 & 3 years & Statewide & $<500$ & 1 & 5 years \\
\hline $\begin{array}{l}\text { ISP } \\
7\end{array}$ & Statewide & 1500 & 1 & 1.5 years & Statewide & N/A & 1 & 3 years \\
\hline $\begin{array}{l}\text { ISP } \\
8^{\mathrm{b}}\end{array}$ & Statewide & 1200 & 1 & 2.5 years & National & 5,500 & 4 & 3.5 years \\
\hline $\begin{array}{l}\text { ISP } \\
9^{c}\end{array}$ & Statewide & 130 & 1 & 2 years & & & & \\
\hline $\begin{array}{l}\text { ISP } \\
10\end{array}$ & Statewide & 3,000 & 2 & 3 years & National & 7,000 & 6 & 6 years \\
\hline $\begin{array}{l}\text { ISP } \\
11^{\mathrm{b}}\end{array}$ & Regional & 4,000 & 17 & 5 years & Statewide & 12,000 & 3 & 7 years \\
\hline $\begin{array}{l}\text { ISP } \\
12\end{array}$ & Regional & N/A & 13 & N/A & Statewide & 7,000 & 25 & 5 years \\
\hline $\begin{array}{l}\text { ISP } \\
13\end{array}$ & Regional & 2,000 & 13 & 2 & & & & \\
\hline $\begin{array}{l}\text { ISP } \\
14\end{array}$ & Regional & N/A & 7 & N/A & & & & \\
\hline
\end{tabular}


Table 2: Phase 1 and 2 Respondent Demographics

Notes: ' $N / A$ ' = respondent declined to provide information

a. ISP 5 had been bought out by a software development house and no longer provided public internet access.

b. ISP 8 and 11 had been bought out by other ISPs. These ISPs were included in the followup survey.

c. ISP 9 was no longer in existence.

d. ISP 4 merged with another ISP, which was included in the follow-up survey. The age given is that of the merger.

e. ISP 3 had been bought out by ISP 7

Table 2 details the demographic breakdown of the ISP respondent group in terms of network spread, the number of clients (customers who use the ISP to gain network access), access points (points of presence or network dialup 'on-ramps') and ISP age. The phase 2 demographics show that a number of ISPs that had participated in the earlier stage of the study no longer existed. This change in ISP population was due to ISPs either going out of business (either voluntarily or involuntarily), or being bought out by another ISP.

Takeover behaviour has been common in the ISP market, where providers have been interested in increasing their market spread without undertaking time-consuming infrastructure layout or staff training. ISP setups are instead purchased wholesale and rebranded to match the new owner.

One important implication of this takeover pattern concerns "organisational memory", which describes the mental models (Levitt and March 1988:326) and shared knowledge of an organisation (Fiol 1994). This organisational memory includes individuals, structure, culture, transformations and ecology (Walsh and Ungson 1991). If some of the original personnel are retained after the takeover, those organisations may maintain some of their previous organisational memory. This may cloud the longitudinal analysis of these firms, as the researcher would be unable to determine whether the opinions given relate to the new organisation or the old one. The effect of this implication is uncertain.

\section{RESULTS}

This section details the results of the study. Reaction to the legislation during the first round of surveys was mixed. The international ISP was more reserved about the legislation's effects, while smaller inner city ISPs signalled that their course of action would depend on those of competitors. Rural ISPs appeared to be more passionate about the possible effects of the legislation. Apart from these three points, there appeared to be little variation across ISP size or age.

\section{Effect on ISP Operations}

In the first round of surveys, most respondents were unclear about the immediate effect on operations. Most respondents predicted immediate and sizeable expenditures on mandatory filtering hardware and staffing. In general, respondent ISPs signalled that these costs would be borne by customers. Two respondents also argued that the additional costs could provoke a "make or break" situation particularly among smaller ISPs, as the alternative to the installation of new hardware was significant fines: "two or three fines of AUS\$27,500 (approximately US\$14,000) will kill our business". 
The second round of surveys painted a different picture. Only two respondents noted any change in operations. ISP 4 now offers filtering software to new dialup clients and ISP 11 now enforces user age verification for websites containing adult content, "just like overseas". No other respondents had seen any cost increases, internal policy changes or other modifications to operations: "we haven't had to hire any extra staff or anything".

\section{Feedback From Clients}

In the first survey, respondents noted that client feedback had been mixed. Some clients had simply been unaware of the legislation, its meaning or its effects. One ISP respondent stated that they had received no feedback despite having informed clients of the legislation. Other ISPs signalled that commercial clients had been changing their plans for future Internet use: one client had abandoned their entire online e-commerce venture. Some parents and schools had been vocal in their protests against the legislation: parents were "outraged at the government's taking control out of their hands".

The follow-up survey showed similar findings: respondent feedback clearly fell into two points of view. The first point of view was that some ISPs observed little in terms of client feedback. One national ISP said, "it doesn't bother most people: it's just business as usual”. ISP 11 noted that, with respect to clients, and despite all the emails circulating at the time of the legislation's introduction, "it had been a total non-event". The other point of view expressed by respondents was that they had received negative feedback from clients. "Australia is seen as draconian with its attitude to the 'net", argued ISP 1. "People don't want to be told what to look at", said ISP 7. These ISPs also noted that this negative client feedback has had little real effect on operations.

\section{Effect on Online Industry}

In the first phase of this study, most respondents foreshadowed adverse effects of the legislation. One statewide ISP argued that the legislation would damage smaller ISPs who did not have the technical or financial support to sufficiently address the complaints or legislative stipulations. One ISP noted that the legislation would be a barrier to commercial website or e-commerce adoption because it increased the cost to the ISP of providing online access. One outcome, signaled by almost every ISP in the first phase of the study, was that content would move offshore where such restrictions were not present. One ISP was constructing servers in France and the United States in order to deal with this issue. This threatened a reduction in Australian Internet providers and a possible fall in the number of commercial web users.

Some two years later, the ISP landscape has changed dramatically, as foreshadowed by respondents in the first stage of the study. However, in contrast to these arguments, many smaller ISPs are still operational (ISP 6, for instance, still had fewer than 500 dialup clients). Additionally, the recent "dot-com" downturn may have affected global ISP numbers.

In the follow-up survey, only one respondent noticed any industry effects. ISP 4 had blamed part of the online downturn on the legislation. All other respondents observed minimal or no change in online industry. ISP 8 argued, "our discussion groups have shown no effects at all on the industry - hosting prices in Australia are uncompetitive anyway so people look elsewhere for hosting porno sites". Another respondent echoed this: "sites can just go elsewhere and everybody knows it". ISP 12 discussed their initial concerns over the 
vast number of complaints they would receive: "that influx has never eventuated".

\section{Implementation Issues}

Most of the ISPs surveyed, irrespective of the degree of network spread, held that the legislation would be difficult to enforce. Problems of policy implementation included the ease with which local content, once removed, or foreign content, once blocked, could easily be moved or republished elsewhere. ISPs were required to undertake the technical process of restricting content access, however users can still access the material itself.

Respondents in the first stage also argued that sites that keyword blocking was unlikely to work. One rural ISP respondent noted that some of their clients maintained sites on animal breeding: respondents had been concerned that these sites might be automatically blocked by search engines or could be forced to adopt age verification measures. Similar sentiments were raised concerning sites discussing safe sex and advocating STD awareness.

The second stage of the survey showed very few implementation issues among those ISPs left in the respondent group. ISP 10 signalled no loss of business, however three ISPs argued that the online industry in Australia has already suffered because of its small ISP population and "rorting from the [telecommunications] monopolies". One ISP did argue that, "if the objective is to protect people from porn and such material...people can get this stuff elsewhere if they really want to. It's more of a public relations scheme to give the impression that [the government is] trying to do something". This suggests that ISPs do not perceive the legislation's effect to have met with its original goals.

\section{Comments on the Legislation}

In the first stage of the study, respondents generally felt the legislation was vague (the section concerning provider indemnification, in particular). Specifically, respondents were concerned that a single indemnification rule would apply regardless of the difficulty associated with blocking the site. Most respondents argued for user-moderated censorship instead: an international ISP argued for "education, empowerment and enforcement", while a smaller local ISP suggested that users should be informed of how to restrict their own net usage.

One respondent argued that given the expense of implementing and maintaining the legislation it would have been cheaper for the government to purchase copies of filtering software to distribute to all Internet users in Australia. Another respondent argued that if this software was too technical, a local software developer could be engaged to develop an acceptable piece of filtering software.

Two smaller ISPs argued that the legislation should be rescinded as the regulation would hurt business but would not prevent access to offensive material: "it's like asking [a motor vehicle manufacturer] to build a car that doesn't crash".

The second stage of the study saw similar comments, despite the apparent lack of effect in the industry. Respondents were generally still opposed to the legislation: "Prohibition does not work", "if people want to have these things blocked, they should take care of it themselves and buy the relevant software" and "it's down to the parents to take responsibility for what their kids are doing". Interestingly, respondents across the study signalled that they fully supported restricting access to "sensitive" material. 
Table 3: Summary of Findings

\begin{tabular}{|l|l|l|}
\hline & Phase 1 & Phase 2 \\
\hline Effect on Operations & $\begin{array}{l}\text { Increase in system acquisition } \\
\text { Increase in costs due to } \\
\text { implementation, monitoring and } \\
\text { fines } \\
\text { Increase in staff to undertake } \\
\text { monitoring }\end{array}$ & $\begin{array}{l}\text { No significant change in } \\
\text { operations }\end{array}$ \\
\hline $\begin{array}{l}\text { Feedback from } \\
\text { Clients }\end{array}$ & $\begin{array}{l}\text { Some client feedback } \\
\text { Opposition from parents and } \\
\text { schools in particular }\end{array}$ & Little feedback overall \\
\hline $\begin{array}{l}\text { Effect on Online } \\
\text { Industry }\end{array}$ & $\begin{array}{l}\text { Fall in commercial web use } \\
\text { Fall in ISP numbers as costs rise } \\
\text { and client numbers drop } \\
\text { Content moving offshore }\end{array}$ & $\begin{array}{l}\text { Fewer ISPs in marketplace } \\
\text { No other industry effects }\end{array}$ \\
\hline $\begin{array}{l}\text { Implementation } \\
\text { Issues }\end{array}$ & $\begin{array}{l}\text { Difficulty in effectively } \\
\text { removing/blocking content } \\
\text { Confusion regarding legislation } \\
\text { Some content intrinsically } \\
\text { difficult to block }\end{array}$ & $\begin{array}{l}\text { ISP industry may have } \\
\text { already suffered } \\
\text { No other implementation } \\
\text { issues }\end{array}$ \\
\hline
\end{tabular}

\section{CONCLUSIONS}

In contrast to the findings of Hosein and Whitley (2002) regarding network legislation in the UK, the legislation has had seemingly little effect on the online industry in Australia. This finding also comes despite ISP claims in the first stage of this study to the contrary. It should be noted that whereas the introduction of this legislation may have affected the ISP population directly, its implications in this regard are difficult to gauge given the effect of the recent downturn in e-commerce business and "dot-coms".

The results generally suggest that, in the opinions of the ISPs surveyed, the legislation in its present form may not meet the original goals of effectively controlling or moderating online content, and is hence flawed. Offensive content can be moved elsewhere if the original host is blocked, hence undermining the efficacy of the regulation. In addition, with ISPs being an integral part of the legislation's function, their apparent dissatisfaction with the regulation may also undermine its effectiveness.

The results echo the arguments of authors such as Teo et al. (1997) and Soh et al. (1997), who discuss the importance of governmental support for evolving online technology. While Hulsink and Van Bolhuis (1998) advocate the introduction of effective bilateral online standards, the legislation in its present form may hinder the evolution of online commerce in Australia by raising ISP costs (which would be passed on to clients) or deterring online ventures. These implications would support the arguments of Williams (1994) that online regulation and legislation may have negligible or even adverse effects on the technology and its users. Several respondents argued that this legislation would have little effect outside Australia; it is possible, however, that given the legislation's potential effect on domestic electronic commerce, global electronic commerce could be adversely affected if similar articles of legislation were to be introduced in other countries. This evidence would seem to support the arguments of authors such as Clarke (1995) and Lambrick (1996), who note that government regulation, improperly implemented, can have stifling and detrimental 
effects on system use.

The results from this research have three main implications. First, regulators should be prepared for significant resistance from network access providers over the introduction of regulatory legislation. This is consistent with the introduction of legislation in other environments (Stigler 1971). The results seem to suggest however, that this resistance could be alleviated through discussion with industry stakeholders. Resistance may also be alleviated through a more open or higher profile review process. As Kawamoto (1997:103) argues, "[reform] can be significantly advanced when a number of sectors are dealt with simultaneously, because that makes it more difficult for special interests to resist reform given the higher political profile and more transparent policy agenda".

The findings highlight the difficulty of legislating for and regulating rapidly changing technology groups. This generally supports the arguments of authors such as Post (1995) and Chong (1995), who observe that conventional legislation may be ineffective in online environments. The results also suggest, however, that this new online legislation has been of questionable benefit to regulators, ISPs and policy makers. While new provisions have been written in order to adapt the conventional legislation for these new environments and hence improve the legislation's effectiveness, the findings also suggest that the enforcement of this legislation is of significant importance. However, as Stigler (1970:526) observes, "There is one decisive reason why the society must forego complete enforcement of the rule: enforcement is costly". Further, this difficulty is increased if the underlying technology is frequently changing.

On a methodological note, the study highlights the difficulties associated with researching online environments. The rapidly changing technology coupled with the keen competition in the online marketplace mean that respondents are often reluctant to divulge information about their operations or strategy. This may explain the dearth of research material in the area: despite the importance of this topic to many groups, scholarly research may simply prove too difficult to undertake. The degree and effect of these implications is uncertain, and their exploration remains an avenue for further research.

The study is subject to a number of important limitations. The study examines only a small sample of the ISP population in Australia, which recent figures place at approximately six hundred access providers. These numbers have been falling over the past twelve months, which would be consistent with the demographic findings presented here. This changing population poses significant problems for longitudinal research in the area. Also, in the interests of expeditious analysis, a telephone survey was used in both phases of the research. While every effort was made to maintain high levels of reliability and comparability between interviews through the use of a structured question sheet, these issues could not be guaranteed.

It could be argued that only those ISPs who were not affected by the legislation were left in the sample group by the time the second phase began. That is, ISPs for whom legislative compliance proved to be too problematic may have expired. The same could be said for those firms who have moved offshore (consistent with Hosein and Whitley 2002). Similarly, if the legislation was as easy to circumvent as was suggested in the earlier stages of the study, subsequent surveys would reveal no significant implementation issues or effects. Both of these issues may explain the lack of variation between responses in the second phase of the study.

A range of possible research topics would be of benefit and interest to the Information Systems discipline as a result of this research. This paper is an investigation into reactions to legislation regarding Internet content restrictions. If further bills are passed through 
parliament, studies should examine the different ways the ISPs in this study are dealing with the new requirements on their business operations. This research could be conducted with respect to their current operational position and stance on the regulation issue. Particular attention should be paid to the movement of ISPs and their clients given the evidence presented here.

Additional research could also focus on other interest groups. For instance, if one of the legislation's original goals was to moderate offensive online content, then some scholarly analysis of the amount of offensive material available would be of benefit. Similarly, it would be interesting to see how parents have reacted to the legislation. An analysis of their attitude to the type and degree of content available online would make for a most fascinating study. Additionally, while the legislation was designed to affect online content, it does not apply to email transaction. Malicious, offensive or irrelevant email can be detrimental to productivity in the workplace (Peat 2002). It would be beneficial to see if employers have noticed changes in the Internet use habits of their staff over the period of the legislation's introduction. This study adds evidence to the ongoing debate surrounding online regulation. While the immediate effects of this evidence are undetermined, the area makes a healthy environment for future research.

\section{REFERENCES}

Abell, W., Lim, L., (1996), "Business Use of the Internet in New Zealand: An Exploratory Study", AusWeb 96 Proceedings, 33 - 39.

ABS, (2000), Household Use of Information Technology, Australian Bureau of Statistics, Australia.

Altmann, J., Chu, K., (2001), "How to Charge for Network Services - Flat-Rate or UsageBased?", Computer Networks, Vol. 36, No. 5-6, 519-531.

Anastasi, A., (1988) Psychological Testing, Sixth Edition, New York: Macmillan Publishers.

Applegate, L. M., Holsapple, C. W., Kalakota, R., Radermacher, F. J., Whinston, A. B., (1996), "Electronic Commerce: Building Blocks of New Business Opportunity", Journal of Organisational Computing and Electronic Commerce, Vol. 6, No. 1, 1-10.

Baldwin, R., Abel-Smith, B., Cave, M., Fenn, P., Hodges, M., Marsden, C., Mossialos, E., Scott, C., Woolcock, S., (1995), Regulation in Question: The Growing Agenda, London: Merck, Sharp and Dohme.

Barringer, B. R., Harrison, J. S., (2000), "Walking a Tightrope: Creating Value Through Interorganizational Relationships", Journal of Management, Vol. 26, No. 3, 367-403.

Bauer, J. M., Berne, M., Maitland, C. F., (2002),"Internet Access in the European Union and in the United States", Telematics and Informatics, Vol. 19, No. 2, 117-137

Baumer, D. L., Earp, J. B., Poindexter, J. C., (2004),"Internet Privacy Law: a Comparison Between the United States and the European Union", Computers \& Security, Vol. 23, No. $5,400-412$

Bhimani, A., (1996), "Securing the Commercial Internet", Communications of the ACM, Vol. 39, No. 6, 29 - 35.

Brien, C., (1996), "Internet: The New Trade in Goods, Services and Ideas", Journal of Law and Information Science, Vol. 7, No. 1.

Bruvold N. T., Comer, J., (1988), "A Model for Estimating the Response Rate to a Mailed Survey", Journal of Business Research, Vol. 16, No. 2, 101-116.

Carr, I., Williams, K., (1994), "The Singapore Computer Misuse Act - Better Protection for the Victims?", Journal of Law and Information Science, Vol. 5, No. 2, 210 - 226. 
Cazavos, E. A., (1996), “The Legal Risks of Setting Up Shop in Cyberspace”, Journal of Organisational Computing and Electronic Commerce, Vol. 6, No. 1, 51-60.

Chiou, J., (2004), "The Antecedents of Consumers' Loyalty Toward Internet Service Providers", Information \& Management, Vol. 41, No. 6, 685-695

Chong, R. B., (1995), "Trends in Communication and Other Musings on Our Future", Federal Communications Law Journal, Vol. 47, 213-219.

Clarke, R. A., (1995), “A Normative Regulatory Framework for Computer Matching”, The John Marshall Journal of Computer and Information Law, Vol. 13, No. 4, 585 -633.

Clarke, R., (1992), “A Contingency Model of EDI's Impact on Industry Sectors”, Journal of Strategic Information Systems, Vol. 1, No. 3, 143 - 151.

Cook, T. D., Campbell, D. T., (1979), Quasi-Experimentation: Design and Analytical Issues for Field Settings, Chicago, Rand McNally Publishers.

Cook, C., Creyke, R., Geddes, R., Holloway, I., (2005), Laying Down the Law, $6^{\text {th }}$ Ed., Lexis Nexis Butterworths, NSW, Australia

De Souza, M., (1999), “Should Net Content be Regulated?”, Internet.au Magazine, June.

Diamantopoulos, A., Schlegelmilch, B. B., (1996), "Determinants of Industrial Mail Survey Response: A Survey-on-Surveys Analysis of Researchers' and Managers' Views", Journal of Marketing Management, Vol. 12, 505-531.

Dillman, D. A., (1978), Mail and Telephone Surveys: The Total Design Method, New York: John Wiley and Sons.

Downes, T., Greenstein, S., (2001), "Universal Access and Local Internet Markets in the US", Research Policy, Vol. 31, No. 7, 1035 - 1052.

Dubin, R., (1978), Theory Building, New York, Free Press.

Easton, D., (1957), "An Approach to the Analysis of Political Systems", World Politics, Vol. 9, No. 3, 383-400.

Fan, Q., (2005), "Regulatory Factors Influencing Internet Access in Australia and China: a Comparative Analysis", Telecommunications Policy, Vol. 29, No. 2-3, 191-203

Feher, A., Towell, E., (1997), "Business Use of the Internet", Internet Research: Electronic Networking and Policy, Vol. 7, No. 3, $195-200$.

Fiol, C. M., (1994), "Consensus, Diversity, and Learning in Organizations”, Organization Science, Vol. 5, No. 3, 403-420.

Forcht, K. A., Fore, R. E., (1995), "Security Issues and Concerns with the Internet", Internet Research: Electronic Networking Applications and Policy, Vol. 5, No. 3, 23 - 31.

Foros, O., Hansen, B., (2001), "Competition and Compatibility Among Internet Service Providers", Information Economics and Policy, Vol. 13, No. 4, 411-425.

Francalanci, C., Willcocks, L., Kern, T., (2001), "Internet and the Horizontal Integration of IT Businesses", European Management Journal, Vol. 19, No. 2, 145-156.

Fraser, C., Hite, R. E., Sauer, P. L., (1988), "Increasing Contributions in Solicitation Campaigns: the Use of Large and Small Anchor Points", Journal of Consumer Research, Vol. 15, 284-287.

Frohlich, M. T., (2002), “Techniques for Improving Response Rates in OM Survey Research”, Journal of Operations Management, Vol. 20, No. 1, 53-62 .

Galliers, D., (1992) Information Systems Research, Blackwells, Oxford, UK.

Gefen, D., Straub, D. W., (2004), "Consumer Trust in B2C e-Commerce and the Importance of Social Presence: Experiments in e-Products and e-Services", Omega, Vol. 32, No. 6, 407424

Gibson, H., (2000), "Shooting the Messenger: A Critique of Australia's Internet Content Regulation Regime", Issue Analysis, Vol. 10, 1-11. 
Graeff, T. R., (2002), "Uninformed Response Bias in Telephone Surveys”, Journal of Business Research, Vol. 55, No. 3, 251-259.

Hallahan, K., (2004),"Protecting an Organization's Digital Public Relations Assets", Public Relations Review, Vol. 30, No. 3, 255-268

Hancher, L., Moran, M., (1989), "Organizing Regulatory Space”, In: Hancher, L., Moran, M., Eds, Capitalism, Culture and Regulation, Claredon Press, Oxford

Hancock, B., (1999), "Security Views", Computers and Security, Vol. 18, No. 3.

Hawkins, D. I., Coney, K. A., (1981), "Uninformed Response Error in Survey Research", Journal of Market Research, Vol. 18, 370-374.

Heilbronn, G., Latimer, P., Nielsen, J., (2005), Introducing the Law, $6^{\text {th }}$ Ed, CCH, Sydney, Australia

Hessler, R. M., (1992), Social Research Methods, St. Paul: West Publishing Company.

Hogwood, B. W., Gunn, L. A., (1991), Policy Analysis for the Real World, Oxford, UK: Oxford University Press.

Hosein, I., Whitley, E. A., (2002), "The Regulation of Electronic Commerce: Learning From the UK's RIP Act", The Journal of Strategic Information Systems, Vol. 11, No. 1, 31-58.

Hulsink, W., Van Bolhuis, H., (1998), "Electronic Commerce and Cyber Entrepreneurship Potential and Problems of European Startup Firms in ICT", 11th Conference on Electronic Commerce, Bled.

Jarvenpaa, S. L., Todd, P. A., (1996), “Consumer Reactions to Electronic Shopping on the World Wide Web", International Journal of Electronic Commerce, Vol. 1, No. 2, 59 88.

Jia, J. H., (2003), "Internet Copyright Regulation - China: Copyright Infringement in the Network Environment - China's Perspective", Computer Law \& Security Report, Vol. 19, No. 2, 101-111

Katzer, J., Cook, K. H., Crouch, W. W., (1982), Evaluating Information: A Guide for Users of Social Science Research, Boston: McGraw-Hill Publishers.

Kawamoto, A., (1997), "Regulatory Reform on the International Trade Policy Agenda", The Journal of World Trade, Vol. 31, No. 4, 81-116.

Kerlinger, F. N., (1986), Foundations of Behavioural Research, New York: Holt, Rinehart and Winston.

Klassen, R. D., Jacobs, J., (2001), "Experimental Comparison of Web, Electronic and Mail Survey Technologies in Operations Management", Journal of Operations Management, Vol. 19, No. 6, 713-728.

Kleinrock, L., (2004),"The Internet Rules of Engagement: Then and Now", Technology in Society, Vol. 26, No. 2-3, 193-207

Koomen, K., (1998), "Illegal and Harmful Content on the Internet: Some Issues and Options", Computers and Law, Vol. 35, No. 1.

Lambrick, J., (1996), "Censorship and the Internet - Not a Good Start", Computers and Law, $3-4$.

Levitt, B., March, J. G., (1988), “Organizational Learning”, Annual Review of Sociology, Vol. 14, No. 3, 319-340.

Libertus.net, "Censorship in Australia - History from 1920 to 1995", http://libertus.net/censor/hist20on.html (2005), Accessed February 5, 2005.

Liefeld, J. P., (1988), "Response Effects in Computer-Administered Questioning”, Journal of Marketing Research, Vol. 25, No. 4, 405-409.

Lu, M., Yeung, W., (1998), “A Framework for Effective Commercial Web Application Development”, Internet Research: Electronic Networking Applications and Policy, 
Vol. 8, No. 2, 166-173.

Madden, G., Savage, S. J., Coble-Neal, G., (1999), "Subscriber Churn in the Australian ISP Market", Information Economics and Policy, Vol. 11, No. 2, 195-207.

Malhotra, M. K., Grover, V., (1998), "An Assessment of Survey Research in POM: From Constructs to Theory", Journal of Operations Management, Vol. 16, No. 4, 407-425.

McLennan, S., (1999) Yearbook Australia, Australian Bureau of Statistics, Government Publishing Service.

Naldi, M., (2002), "Internet Access Traffic Sharing in a Multi-Operator Environment", Computer Networks, Vol. 38, No. 6, 809-824.

Ng, H., Pan, Y. J., Wilson, T. D., (1998), "Business Use of the World Wide Web: a Report on Further Investigations", Information Research, Vol. 3, No. 4, 291 - 314.

Nicholls, W. L., Baker, R. P., Martin, J., (1997), "The Effect of New Data Collection Technologies on Survey Data Quality", in Lyberg, L., Biemer, P., Collins, M., et al. (Eds.), Survey Measurement and Process Quality, New York: Wiley Publishers, 221-248.

Nunamaker, J. F., Chen, M., Purdin, T. D. M., (1991), "Systems Development in Information Systems Research”, Journal of Management Information Systems, Vol. 7, No. 3, 89 106.

Parker, L., (1992), "Collecting Data the E-mail Way”, Training and Development, 52-54.

Peat, G., (2002), "The Threat of Malicious Outbound Email”, Computer Fraud \& Security, 2002, 4, 10-11.

Peltzman, S. (1995), The Economic Theory of Regulation after a Decade of Deregulation, The Political Economy of Privatisation and Deregulation, Elgar Reference Collection,

International Library of Critical Writings in Economics, 44, Aldershot, UK, 168-208.

Post, D., (1995), “New Rules for the Net?”, The American Lawyer, 112.

Ramsay, I., (1985), "Framework for Regulation of the Consumer Marketplace”, Journal of Consumer Policy, Vol. 8, 353-372.

Robey, D., Boudreau, M., Rose, G. M., (2000), "Information Technology and Organizational Learning: a Review and Assessment of Research", Accounting, Management and Information Technologies, Vol. 10, No. 2, 125-155.

Rose, R., (1973), “Comparing Public Policy: An Overview”, European Journal of Political Research, Vol. 1, 67-96.

Salam, A. F., Pegels, C. C., Rao, H. R., (1997) “An Exploratory Investigation of the Internet Involvement: Instrument Development, Measurement and Implications for Electronic Commerce", Association of Information Systems Conference Proceedings.

Schneider, K. C., Johnson, K. C., (1995), "Stimulating Response to Market Surveys of Business Professionals", Industrial Marketing Management, Vol. 24, 265-276.

Schuldt, B. A. Totten, J. W., (1994), "Electronic Mail vs. Mail Survey Response Rates", Marketing Research: A Magazine of Management and Applications, Vol. 6, No. 1, 3639.

Sharkansky, I., (1970), "Environment, Policy, Output and Impact: Problems of Theory and Method in the Analysis of Public Policy”, in I. Sharkansky (Ed.), Policy Analysis and Political Science, Chicago: Markham Publishers.

Soh, S., Mah, Q. Y., Gan, F. J., Chew, D., Reid, E., (1997), "The Use of the Internet for Business: The Experience of Early Adopters in Singapore", Internet Research: Electronic Networking Applications and Policy, Vol. 7, No. 3, 217 - 228.

Stair, R. M., Reynolds, G. W., (1998), Principles of Information Systems: A Managerial Approach, 3rd Edition, Boston, Course Publishers.

Stanton, J. M., (1998), “An Empirical Assessment of Data Collection Using the Internet”, 
Personal Psychology, Vol. 51, No. 3, 709-725.

Stephens, J., (1972), “An Appraisal of Some System Approaches in the Study of International Systems", International Studies Quarterly, Vol. 16, No. 3, 321 - 349.

Stern, S. E., Gregor, S., Martin, M. A., Goode, S., Rolfe, J., (2004), "A Classification Tree Analysis of Broadband Adoption in Australian Households", Proceedings of the 6th International Conference on Electronic Commerce, Delft, The Netherlands, 451 - 456

Stigler, G. J., (1970), "The Optimum Enforcement of Laws", The Journal of Political Economy, Vol. 78, No. 3, 526-536.

Stigler, G. J., (1971), “The Theory of Economic Regulation”, The Bell Journal of Economics and Management Science, Vol. 2, No. 1, 3-21.

Straub, D. W., (1989), "Validating Instruments in MIS Research", Management Information Systems Quarterly, Vol. 13, No. 2, 147 - 169.

Strauss J.,Rogerson, K. S., (2002), "Policies for Online Privacy in the United States and the European Union", Telematics and Informatics, Vol. 19, No. 2, 173-192

Tan, M., Teo, T. S. H., (1997), "Factors Influencing the Adoption of the Internet", International Journal of Electronic Commerce, Vol. 2, No. 3, 5 - 18.

Teo, T. S. H., Tan, M., Buk, W., K., (1997), “A Contingency Model of Internet Adoption in Singapore”, International Journal of Electronic Commerce, Vol. 2, No. 2, 95 - 118.

Tian, Y., (2004), "Business Implications of Anti-Circumvention Legislation and Recommendations", Computer Law \& Security Report, Vol. 20, No. 6, NovemberDecember, $445-452$

Trewin, D., (2002), Internet Activity, Publication 8153.0, Australian Bureau of Statistics.

Vadapalli, A., Ramamurthy, K., (1997), "Business Use of the Internet: An Analytical Framework and Exploratory Case Study", International Journal of Electronic Commerce, Vol. 2, No. 2, $71-94$.

Walsh, J. P., Ungson, G. R., (1991), “Organizational Memory”, Academy of Management Review, Vol. 16, No. 1, 57-91.

Walsham, G., (1993), Interpreting Information Systems in Organisations, Chichester, UK: Wiley Publishing.

Weible, R., Wallace, J., (1998), “Cyber Research: the Impact of the Internet on Data Collection", Marketing Research, Vol. 10, No. 3, 19-25.

Williams, T. A., (1994), "Government Regulation Through Voluntary Cooperation: the Strategic Impact of Information Technology", Journal of Strategic Information Systems, Vol. 3, No. 2, 149-156.

Wright, H., (1996a), “The Net: The Beginning or the End for Free Expression?”, Computers and Law, Vol. 29, 4 - 5 .

Wright, H., (1996b), "Convergence and Communication Values on the Net", Journal of Law and Information Science, Vol. 7, No. 1.

Xiao, J., Yang, H., Chow, C. W., (2004), "The Determinants and Characteristics of Voluntary Internet-Based Disclosures by Listed Chinese Companies", Journal of Accounting and Public Policy, Vol. 23, No. 3, 191-225

Yemini, Y., Dailianas, A., Florissi, D., Huberman, G., (2000), "MarketNet: Protecting Access to Information Systems Through Financial Market Controls", Decision Support Systems, Vol. 28, No. 1-2, 205-216. 


\section{APPENDIX A}

Telephone Questionnaire Sheet

ISP Name:

How many clients do you have (approx.)?

How many access points do you have?

How old is the ISP business?

(specify years or months)

Does the respondent know about the legislation?

(Yes or No)

People can complain to the Australian Broadcasting Authority about offensive online material

This material will receive a rating by the National Classification Board (e.g. X or R)

The Australian Broadcasting Authority can then issue notice to ISP to either remove material if it is local or block it if it is foreign. The ABA can also issue an interim removal notice pending a decision.

Will this legislation have an impact on your operations? (Why or why not? Please give details)

Know

Have you had any positive feedback (from any sector) yet?

Know

Have you had any negative feedback (from any sector) yet?

Know

How does the respondent feel this will affect the online industry, if at all?

Know

Could the legislation be improved? If so, how? 
AJIS Vol 13, No. 1

September 2005

$\square$ Don't

Know

Does the respondent have any comments about policing within the ISP?

$\square$ Don't

Know

Does the respondent have personal feelings on the matter?

$\square$ Don't

Know

Would the respondent like a copy of the results? If so, please give address:

Know 